\title{
DECISION-MAKING BEHAVIOR OF LOAN RESTRUCTURING BASED ON INSTITUTIONAL LOGICS: CASE STUDY BANK PERKREDITAN RAKYAT INDUSTRY IN WEST JAVA REGION
}

\author{
Sugiarto Kasmuri ${ }^{{ }^{*}}$ and Elvia R. Shauki ${ }^{2}$ \\ ${ }^{1,2}$ Universitas Indonesia, Depok, Indonesia
}

\begin{abstract}
This research examines the phenomena of loan restructuring decision behavior carried out by BPRs' actors (loan officers or loan managers) in West Java Province. It is aimed to answer the research questions: why rural banks (BPRs) as institutional fields pay less attention to loan restructuring to recover the accounting losses from the provision of problem loans. According to Otoritas Jasa Keuangan (2017), 94 out of 290 BPRs in West Java Province did not feel eager to restructure the problem loans despite having a ratio of Non-Performing Loans (NPL) more than 5\% threshold. The behavior itself could be motivated by both symbolic factors and material factors as carriers for their behavior. Two prior studies conducted by Micucci and Rossi (2010), Dardac, Barbu, and Boitan (2011) examined loan restructuring based on policies and its impact on banks as institutional but did not reveal the behavioral side of the restructuring decision-making proceed by an individual of loan managers and loan officers. Thus, this study is aimed at observing the individual motivation of actors symbolized by loan managers and loan officers in rural banks (BPRs) in West Java Province. The analysis of decision taken by loan officers or loan managers in this study uses an institutional logic basis which theory focuses on the logic of actors both individually or collectively in such a particular economic sector. The results explain that symbolic carriers (regulations and accounting standards) and material carriers (informal practices, routines, individual target, accounting practice difficulties) revealed the phenomena related the behaviour of actors' (loan managers and loan officers) in BPR which put less attention on loan restructuring - as one of the credit risk mitigation for troubled debt. Second, there is similarity for actors to avoid the troubled debt restructuring due to some difficulties in recognizing loss occurred in the beginning period of restructuring.
\end{abstract}

Keywords: And Accounting Practice, Behavior, Institutional Logics, Loss On Restructuring, Material Carriers, Motivation, Symbolic Carriers.

\section{INTRODUCTION}

The banking industry in Indonesia has its uniqueness. Banking Act Number 10 the year 1998 concerning Amendments to Banking Act Number 7 the year 1992 classifies banks in Indonesia into Commercial Banks and Bank Perkreditan Rakyat (BPR). According to these Acts, Rural Banks have similar business entities as Commercial Banks in raising funds from public and lending money to improve the lives of people. However, there are restrictions in BPR business activities, such as opening branches prohibited outside one province and product services are only permitted to take deposits in the form of time deposits, savings, and/or other similar forms.

The Otoritas Jasa Keuangan (2017) recorded there are 1,619 BPRs with 6,192 offices. The region which has the highest number of BPRs is West Java Province by 290 BPRs and 1,054 BPR offices operating actively. Generally, business activities of BPRs (OJK, 2017) are dominated by loans, which its portion approximately $71 \%$ of the total assets of BPRs concentrating on micro and small lending segments.

Based on Indonesian Banking Statistics in 2017 published by OJK (2017), NPL of BPRs was only $4.75 \%$ or still below the OJK threshold of $5 \%$ for the year 2014 , but it began to deteriorate beyond the 5\% limit, reaching 5, 83\% at the end of the year 2015 .

* Corresponding author. Email address : skasmuri@gmail.com 
It continued getting worse until end of the third quarter of the year 2017 by $7.00 \%$ and slightly decreased at the end of 2017 to $6.15 \%$ (but remained out of the 5\% limit allowed) as presented in Figure 1.

Figure 1 BPRs' Loan Performance in Indonesia

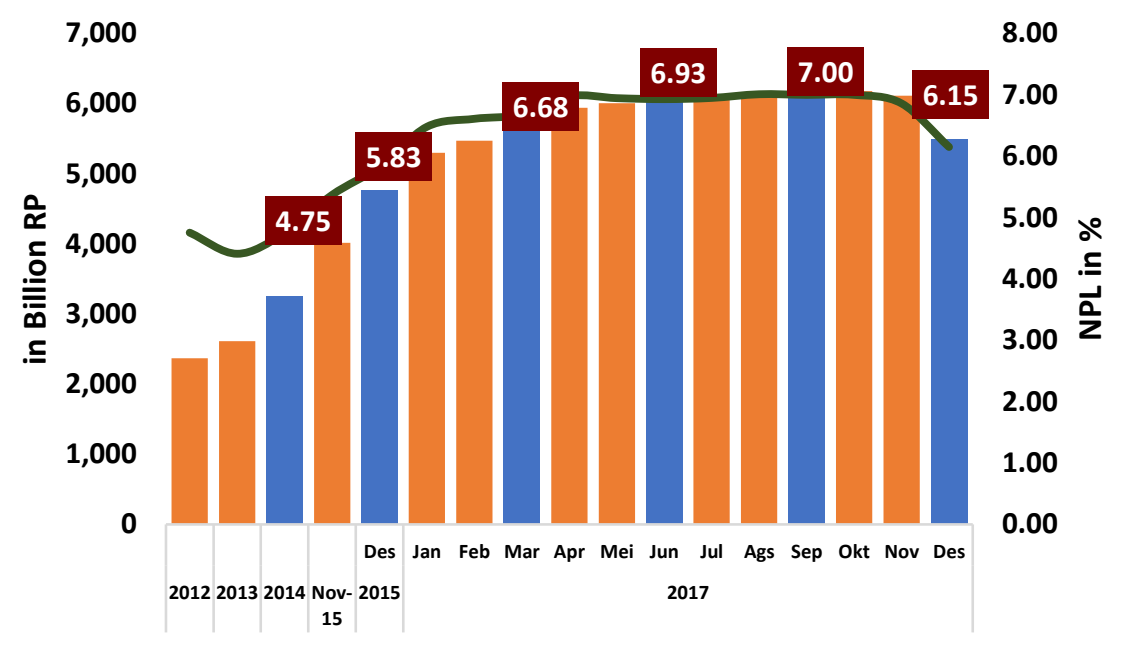

Furthermore, OJK (2017) noted that there are 94 out of 290 BPRs in the West Java region which have not carried out loan restructuring though having NPL ratio above 5\% (see Appendix 1). It showed a change that BPRs industry tended to ignore restructuring for non-performing loans. Meanwhile, uncontrolled non-performing loans could have consequences for BPR - deterioration BPR performance and depositors trust. Www.bisnis.com dated on November 27, 2017, quoted Indonesia Deposit Insurance Corporation/Lembaga Penjamin Simpanan (IDIC/LPS) statement that 76 BPRs has been liquidated including 30 BPRs in the West Java Province until September 2017 due to inadequate strategy in carrying out credit risk management.

On the other hand, banking consumers are quite interesting to consider the possibility of proposing loan restructuring to pay their debts. OJK reported $20 \%$ of total information requests for banking consumer in the fourth quarter of the year 2017 were related to loan restructuring (OJK 2017).

There are not many earlier studies related to behavior changes of loan restructuring in the context of BPR industry. Two previous researches conducted by Micucci and Rossi (2010) and Dardac, Barbu, and Boitan (2011) examined loan restructuring based on policies and their impact on banks, but it did not reveal the behavioral side of the restructuring decision-making process of related parties such as credit managers and loan officers.

The study is motivated by the following research questions: (1) why does the behavior of Material Carriers (Actors) pay less attention in following up on the restructuring request for non-performing loans in institutional fields (BPR), and (2) what is the behavior of Material Carriers (Actors and Artefacts) in fulfilling the requirements governed by Symbolic Carriers (rules and customs) to answer the Isomorphic (similarity) practices within the BPR industry environment in regard with decision to restructure or non-restructure non-performing loans at BPR? In particular, the study is aimed to look at the motivation of loan officers and loan managers.

\section{LITERATURE REVIEW}

\section{Prior Studies}

Under certain conditions when borrowers face financial problems, so they are challenging to fulfil their credit obligations, BPRs may have the option to restructure the loans. Loan restructuring is carried out because the borrowers may still have profit on their operations (Micucci and Rossi, 2010). When a debtor faces a problem of 
financial difficulties, the bank that provides the loan needs to decide whether it needs to be secured or not. Previous research conducted by Dardac, Barbu, and Boitan (2011) explained the impact of credit restructuring on the quality of bank loan portfolios using the cluster analysis approach and concluded that there was a risk of the debtor returning to failure despite restructuring and returning loan become nonperforming. It is recognized as a process of allocation of losses between the borrower and lender. However, those two prior studies examined credit restructuring based on policies and their impact on banks but did not reveal the behavioral side of the restructuring decision-making process of related parties such as credit managers and loan officers.

Contrast to those two studies, the research conducted by Laryea (2010) emphasized that the success of loan restructuring applied operational restructuring focused on the structure and efficiency of the debtor business. Also, government interference through regulations was not only facilitating loan restructuring but also support the success of loan restructuring. Two approaches motivate government intervention according to Laeven and Laryea (2009) is motivated by two approaches: (1) regulation and institutional frameworks that support voluntary restructuring (without going through a court), and (2) the implementation of credit restructuring given incentives from the government such as subsidized interest rates for certain loans or debtors. However, the opinion of Laeven and Laryea (2009), which states that regulations (regulations) and institutional frameworks support the success of credit restructuring, need to be explored further using the Institutional Theory framework. To this context, we focus specifically on 'Institutional Logics' and 'Isomorphism' to gain understanding the behavior of loan managers and loan officers in the choice of restructuring or not restructuring the problem loans.

\section{Institutional Logics}

The Institutional Logics approach was initially introduced by Friedland and Alford (1991), which was subsequently developed by Thornton and Ocasio (1999), providing a comprehensive way of analysing and developing methodologies using different perspectives to solve problems in future research. It focuses on the ability logic to understand the behavior of actors both individually and collectively in specific institutional sectors (Thornton, Ocasio, and Lounsbury, 2012). According to Friedland and Alford (1991), Institutional Logics is a set of material practices and symbolic structures that become principles for institutions or patterns of human activity. Meanwhile, Thornton and Ocasio (1999) distinct Institutional Logics as a historical pattern of material practices, assumptions, values, beliefs, and rules. Based on the view of Friedland and Alford (1991), it is essential to understand the differences between institutional logics and institutions, where institutional logics are more influential than institutions because logics can direct the meaning of institutions and social, even though logics are less real than the institutions themselves. Logics is a set of material and symbolic carriers that guide institutions, such as participation in democratic institutions, or commodification of human activities in capitalist institutions as stated (Friedland and Alford, 1991).

The current perspective was developing more focuses on institutions and the underlying logic of institutions side by side in the community, even though both of institutions and basic logics often create different social arrangements (Johansen and Waldorff, 2015). Institutional Logics are not a pre-existing social structure. It is defined and prepared based on the actions of individuals and organizations, where the relationships of individuals, organizations, and institutions as keys in identifying and analysing logics.

Organizations and people are factors in institutional logics because both are actors or parties that ensure the compatibility of symbolic carriers and material carriers in institutional fields. Thornton, Ocasio, and Lounsbury (2012) explained the primacy of material over symbolic in Institutional Logics with the assumption that material and 
symbolic are used separately. However, material carriers are more real than symbolic carriers. Thus researchers attempt to separate symbolic from structural influences.

\section{Symbolic Carriers}

Symbolic carriers are rules, norms, and beliefs that socially recognize behavior that is considered reasonable and serve as guidelines in organizational practices (Rao, Monin, and Durand, 2003, p.795-796 in Lepoutre and Valente, 2012, p. 286). Symbolic carriers motivate people in organizations and organizations themselves who try to avoid sanctions, uncertainties or inconsistent thoughts that occur together with deviations from the rules, norms, beliefs, and assumptions (DiMaggio and Powell, 1983; Jepperson, 1991; Scott, 2008 in Lepoutre and Valente, 2012, p.286).

The example presented by Zuckerman (1999) was quite relevant in this study. Some organizations deviate from the industry group starting with capital market analysts receiving lower share prices with low ratings, compared to the same organizational performance and industry peer group. The institutionalization process produces interpretations of normative standards that are set and informed by the competent authorities such as the Otoritas Jasa Keuangan (OJK), or precisely mimic practices that many other similar organizations do (DiMaggio and Powell, 1983).

\section{Material Carriers}

Although organizations generally put symbolic carriers as the most critical factor in institutions (Scott, 2008), institutions were also described by Friedland and Alford (1991) and Scott (2008) as material artifacts, routines, and relationships between actors in institutional fields. Boeker (1989), Gilbert (2005) and Staw (1981) propose several reasons that encourage actors in institutions to carry out practices in organizations including reward systems and institutional governance, relationships, routines or habits, and previous contracts or investments.

Thornton and Ocasio (1999), Scott (2008) in Lepoutre and Valente (2012) interpreted carrier materials as routines/habits, relationship systems, and artifacts. Meanwhile, in other studies (Scott, 2008; Zietsma and Lawrence, 2010; Lepoutre and Valente, 2012) explained that material carriers are actors who work individually and collectively and artifacts that are suitable for specific logics. Scott $(1995,2001)$ defines artifacts as material made by human creativity to help carry out tasks.

\section{Isomorphism}

DiMaggio and Powell (1983), Davis (1991), Galaskiewicz and Wasserman (1989), Mizruchi and Stearns (1988), Glynn and Abzug (2002), Tuttle and Dillard (2007) explained isomorphic behavior in which the conformity of specific organizations. The organizational environment was characterized by adopting similar practices, structures, and behaviors which were considered better. DiMaggio and Powell (1983) divided isomorphism into three types. First, coercive isomorphism is politically in nature and arises because of the need to gain legitimacy from other organizations, and the existence of high power from actors such as the state represented by the competent authority. Second, normative isomorphism is the need to adopt practices that are considered good and morally correct by actors such as professionals, whose laws of conformity are usually implicit. Third, mimetic isomorphism is the tendency of some organizations to imitate other organizations that are believed to be successful and legitimate organizations in uncertain conditions even though the success criteria are not real.

Some of the papers have explained mimetic isomorphism, especially underlining the impact of inter-organizational social networks, for example, Davis (1991) in Hambrick, Finkelstein, Cho, and Jackson (2005) described that the adoption of the poison pill anti-takeover defense depended on connections of directors. Moreover, several companies might be able to imitate the pattern of giving charity of other 
institutions to which the top management had social connections, as observed by Galaskiewicz and Wasserman (1998).

Coercive and normative isomorphism in certain practices explained by Mizruchi and Stearns (1988) who found that macroeconomic factors were related to the employment of financial expertise as a member of boards. Glynn and Abzug (2002) revealed the organizations adapt to institutional pressures in undertaking modifications in their company character. Furthermore, Tuttle and Dillard (2007) observed that the institutional field (US Accounting Research) had touched a phase where it is mostly driven by the normative isomorphism.

\section{Loan Restructuring}

According to Gilson, John, and Lang (1990), debt restructuring is a transaction that changes the existing debt contract into a new contract. In the World Bank Study Book "Out of Court Debt Restructuring" which was written by Garrido (2012) explained that in some cases the settlement of non-performing loans (restructuring) proved to be more effective than resolving through formal insolvency procedures. In the study, Garrido (2012) gave the view that a restructuring agreement between debtors and creditors is a contractual agreement that must be supported by norms or principles and the need for intervention from the relevant authorities (regulators) through regulations. The regulations of loan restructuring for BPR industry are Peraturan Bank Indonesia (PBI) Number 13/26 / PBI / 2011 concerning Amendments to PBI Number 8/19 / PBI / 2006 concerning Earning Asset Quality and Establishment of Allowance for Earning Assets of Rural Banks, and PBI Number 8/19 / PBI / 2006 concerning Earning Assets Quality and Allowance for Earning Assets of Rural Banks.

According Bank Indonesia (2006, 2011), loan restructuring is an attempt for BPR lending activities to facilitate the borrower who have financial difficulties for paying their debts, namely: (1) rescheduling through converting the debt payments in the scheme of changes the payment schedule or maturity of the loan, (2) all or partial amount of the loans are changed but not limited to payment schedule changes, the time period and/or the terms of the loans, provided not to alter the maximum initial loan, (3) reconditioning is a change of loan terms with the additional facility amount, the conversion of interest arrears becomes a subject that can be followed by rescheduling and/or credit requirements.

Furthermore, Rural Banks are not permitted to carry out loan restructuring if they only aim to avoid a decline in credit quality, increase the provision of allowance for earning assets (PPAP), and/or terminate recognition of interest income on an accrual basis. To ensure that the conditions are not violated, the regulator checks and corrects loan quality, PPAP and accrued interest accruals if the loan restructuring turns out to be prohibited in restructuring loans, borrowers do not implement credit restructuring agreements, and / or repetition of credit restructuring occurs only to maintain loan quality regardless of the condition and prospects of the debtor's business.

The regulator (OJK) also requires BPRs to comply with the Accounting Standards that apply for BPRs. Standar Akuntansi Entitas Tanpa Akuntabilitas Publik (SAETAP) Year 2009 and Pedoman Akuntansi BPR Year 2010 are two standards set out by regulators. In the case, the cash value is lower of the carrying amount of the loan at the time of restructuring, the difference is recognized as loan restructuring loss. Recognition of these losses is undoubtedly a separate consideration for BPRs in choosing to conduct credit restructuring in resolving non-performing loans. For restructured loans with the addition of credit facilities through the conversion of interest arrears, the addition of the carrying amount of credit must be recognized as deferred interest income. The deferred interest income must be amortized and recognized as interest income if the restructured loan meets the performing criteria by the regulatory provisions. However, if classified as non-performing, the deferred interest income is not amortized and recognized as interest income. 


\section{RESEARCH METHODOLOGY}

\subsection{Research Design}

This research applies a case study as its research strategy. Mixed-method research using a combination of a qualitative and quantitative approach (commonly referred to as blended research) (Thomas, 2003 in Shauki, 2018) is applied in this study to answer the research questions. The mixed-method approach is chosen because the research questions can be examined more focused in a manner entirely. According to Shauki (2018), this approach should be used to obtain better research findings and results in addressing the research questions. It allows researchers to explore more deeply and answers the research problems regarding the motivation or behavior of actors (credit managers or loan officers) for BPR industry within the West Java region in carrying out non-performing loan restructuring and contributing for further research on the behavior of actors of institutional fields in the context of BPR.

This study deploys a mixed-method approach, it combines quantitative and qualitative approaches. In this study, the quantitative approach was performed during data collection stage through a survey and qualitative approach was performed during data analysis stage using content and thematic analyses as discussed by Sieber in Shauki (2018).

According to Shauki (2018), content analysis is an analysis that helps researchers in a quantitative way to code and usually uses an open-ended question to support qualitative analysis. According to Wilkinson and Birmingham (2003) in Shauki (2018), to conduct a content analysis of data from questionnaires, it should be classified in several categories after reliability and validity test. According to Wilkinson and Birmingham (2003) in Shauki (2018), content analysis is a very an essential research instrument over successful information collected through questionnaire, as well as help researchers to identify a pattern in the information obtained.

Content analysis is one of the popular research methods in gathering evidence (Parker, 2005). It is a technique of analyzing written, spoken or visual messages (Cole, 1988), in which systematic and independent in relating, measuring the phenomena behind the research (Krippendorff, 1980 in Shauki, 2018). Elo and Kyngas (2007) in Shauki (2011) advised two types of content analysis: (1) quantitative; and (2) qualitative data. Quantitative content analysis is in the form of data which will be part of the quantitative approach where words frequencies and the number of respondents was performed as a measurement basis. Qualitative analysis utilizing coding data from content analysis covers topics or themes discussed by respondents. Furthermore, Shauki (2018) also illustrates that thematic coding analysis explains the purpose of the actual content and why the content is interesting to explore. Coding descriptions are normally related to who talks about the topic, what organizations are observed, and which data sources explain research themes or topics.

This study employs primary data using open-ended questionnaires and also uses secondary data such as online media, and regulations issued by Bank Indonesia and the Financial Services Authority related to BPR loan restructuring. Questionnaires are research instruments to obtain information from individuals regarding their views or opinions on the topic of research problems (Wilkinson and Birmingham in Shauki, 2018). This study uses questionnaires because it involves so many respondents (loan managers and loan officers of BPR), thus collecting data will be effective, efficient, easier and faster to analyse to research problems regarding the actor's behavior in the BPR industry within West Java Province.

The questionnaires were compiled after obtaining information from the results of a complete and relevant questionnaire. From the results of the questionnaire that has been returned and valid will be a consideration in determining the sample with the loan managers or loan officers. Though, some actors on a small scale of BPRs was represented by the director who has prior experiences as loan managers or loan officers. The selection of respondents was conducted by purposive sampling method. Samples were selected because of specific considerations following the terms and criteria 
representing the population. The criteria of respondents are loan managers or loan officers who have experienced for more than one year. Then it is sorted again with priority to loan managers and loan officers who were working on BPR with NPL levels above 5\%, and the ratio of the amount of loan restructuring is quite low compared to other BPRs. The questionnaires focus on the research questions and expect only for relevant information from respondents.

Respondents are independent persons in answering the survey as no conflict of interest between the authors and respondents. It is reflected that they did not get to associate each other beforehand, and there is also no work relationships and no pressures in fulfilling the questionnaire (voluntary). Survey links are delivered directly via the message applies to their mobile number or e-mail obtained from selected BPRs. Subsequently, we reconfirmed each respondent who had filled the questions to ensure only the right persons can participate in the survey. Moreover, the reliability and validity check is completed by reading all information from respondents. Validation stage is conducted through peer checking by the second researcher. Only complete and relevant data/information to the research questions is analyzed. In order to avoid the existence of a biased method, the research design in this study has been adapted to research problems/research motivations as outlined in research questions.

\subsection{Data Analysis}

In regard to Wilkinson and Birmingham (2003) in Shauki (2018), the researchers used the stages introduced by Wilkinson and Birmingham (2003) in Shauki (2018): (1) Identify the topic of research, (2) Establish content categories, (3) Test the categories generated, (4) Collect data; and (5) Analyse content of data and provide results.

Babbie (1998) has shown the fact that the content analysis approach provides meaning to research that reflects trends in society, so this approach reduces weaknesses in behavioral research. Content analysis is conducted to examine the motivation of managers and/or loan officers of BPRs who have less interest in using loan restructuring as an effort to recover the accounting loss from the provision of nonperforming loans. In-depth research with content analysis is also used to record relevant answers that are conveyed by actors related to loan restructuring and classified into several coding as follows: (1) Regulations (OJK, BI and IAI Accounting Standards), (2) Standard Operating Procedures, (3) Loss on restructuring (influenced by bonuses and incentives), (3) Habits (routines and informal practices, (4) Barriers (application and accounting constraints), (5) Competency and (6) Gap (regulations and practices).

After grouping it into the coding categories above, the researcher recorded all findings using the excel spread sheet, which then proceeded to test the validity through a pre-test. When these steps have completed, all findings based on questionnaires are grouped according to the categories above.

Coding the topic is analysed the contents to explore themes frequently discussed by actors (classified as restructuring or non-restructuring of the loan). Coding descriptions are analysed using thematic analysis which is used to explore the themes discussed by the actors, namely discussions relating to the reluctance or disinterest of the actors to proceed problem loans restructuring. Gray et.a; (1995), Guthrie and Abeysekera (2006), and Elo and Kyngas (2007) in Shauki (2018) suggest that a combination of content analysis using words, sentences, and paragraphs, will be a strong basis for providing empirical explanations such as aversion or disinterest the actors to proceed loan restructuring in this study.

\subsection{Multiple Unit Analysis}

The unit of analysis in this study is a single unit analysis with multiple embedded unit analysis. The objects of the research are the BPR industry in West Java as a single unit analysis and several BPRs as multiple embedded unit analysis. We arrange the BPR industry in the West Java Province as a unit of analysis based on some considerations in which West Java Province is: 
AFEBI Accounting Review (AAR)

Vol.04 No.01, June 2019

1. the highest number of BPR institutions in Indonesia with 290 BPR;

2. the second largest share of total loans and total assets in Indonesia;

3 . the second largest number of problem loans in Indonesia;

4. non-performing loans compared to total loans are $8.29 \%$ or exceeding the $5 \%$ limit; and

5. the loan restructuring compared to total non-performing loans are only $29.54 \%$ (SPI-OJK, 2017).

Almost 60 BPRs in West Java Province were included, this study focused on loan managers and loan officers who have experiences and responsibility to continue the process of loan restructuring application submitted by the borrower. Embedded unit analysis is employed based on these categories in the table below.

\begin{tabular}{|c|c|c|c|c|}
\hline Criteria & $\begin{array}{c}\text { Loan Restructuring: } \\
\text { Total NPL }\end{array}$ & Numbers of BPR & Relative Frequency & Amount of Sample \\
\hline \multirow{2}{*}{ NPL $>10 \%$} & $=0 \%$ & 63 & $21.72 \%$ & 13 \\
\hline & $0<\mathrm{R} \leq 30 \% *)$ & 39 & $13.45 \%$ & 8 \\
\hline \multirow{2}{*}{$5 \%<\mathrm{NPL} \leq 10 \%$} & $=0 \%$ & 31 & $10.69 \%$ & 6 \\
\hline & $0<\mathrm{R} \leq 30 \% *)$ & 20 & $6.90 \%$ & 4 \\
\hline $\mathrm{NPL} \leq 5 \%$ & & 87 & $30.00 \%$ & 18 \\
\hline $\mathrm{NPL}>5 \%$ & $\mathrm{R}>30 \%$ & 50 & $17.24 \%$ & 10 \\
\hline \multicolumn{2}{|c|}{ Total } & 290 & $100 \%$ & 60 \\
\hline
\end{tabular}

*) $30 \%$ is average of ratio the amount of loan restructuring to total NPL

\section{RESULTS AND DISCUSSION}

\subsection{Results}

The most topics that were discussed related to the symbolic carriers and material carriers as the motivation of loan managers and loan officers are outlined in Figure 2.

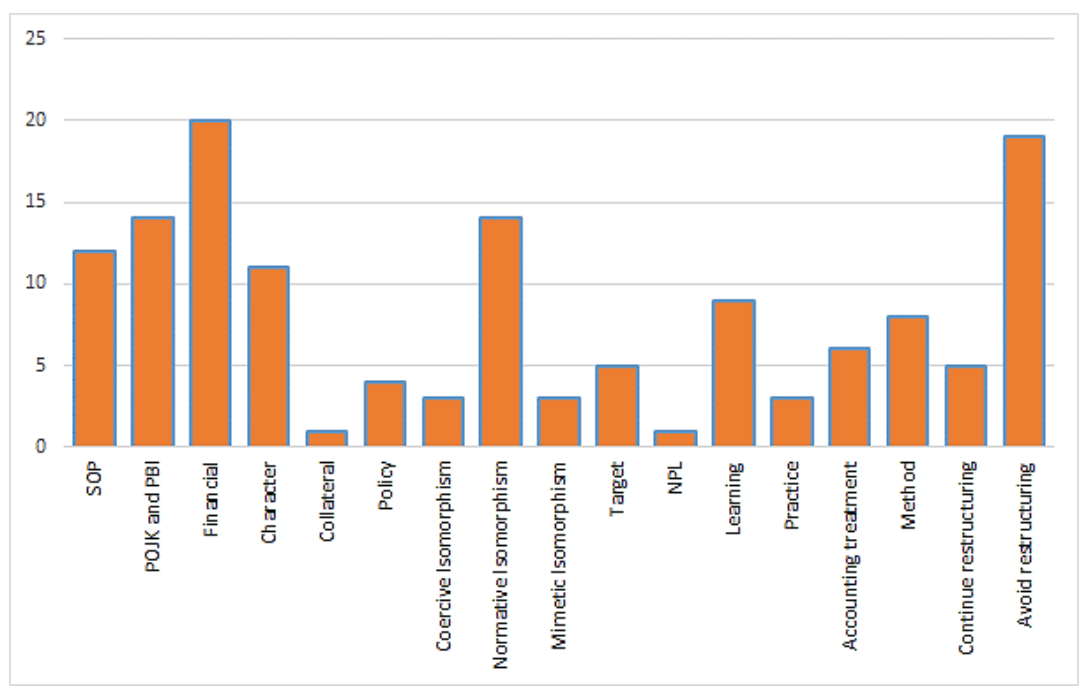

Figure 2 The Most Concerned Topics Discussed

- Symbolic and Material Carriers as Motivation of Loan Managers and Loan Officers

The table, as presented in Appendix 4, shows topics dominate the discussion, as mentioned:

a. Regulations 
Otoritas Jasa Keuangan, Bank Indonesia, and Ikatan Akuntan Indonesia issued the regulations and standard which applied for BPR as guidance in loan restructuring. The response of respondents showed that $100 \%$ of total respondents carrying external and internal regulations as a topic related to loan restructuring, namely the OJK Regulation, Bank Indonesia Regulations, and accounting standards.

b. Isomorphism

Normative isomorphism is the topic dominating the discussion for $69.23 \%$ as compared to both coercive isomorphism and mimetic isomorphism with $17.95 \%$ and $12.82 \%$ respectively. It shows the evidence that loan managers at BPRs have no much different motivations due to the existence of norms or rules believed. As a highly regulated industry, it is common that loan managers and loan officers tend to figure out norms or rules as factors that drive interest or even as a factor that reduces interest in restructuring non-performing loans in BPR.

c. Loss on restructuring

Most of the loan managers and loan officers put consideration in restructuring loss as a factor affecting the decision on loan restructuring. It resulted in $57.14 \%$ of total respondents realized that restructuring losses related to rejecting the proposal submitted by a borrower who experiences financial difficulties. Meanwhile, $42.86 \%$ of respondents tend to ignore the possibility of losses that occur and still want to restructure because they consider the losses incurred insignificant.

d. Norms or Beliefs

Norms and beliefs are two factors influencing informal practices of the decisionmaking process on loan restructuring. The response of respondents reflected this condition. It resulted in $59.96 \%$ of total respondents considered both factors related to the loan restructuring practices in BPR. But, $40.35 \%$ of total respondents have a different opinion, and they think that loan restructuring decision-making is usually not influenced by norms.

e. Competency

Competency is also interesting for loan managers and loan officers, as shown by $100 \%$ of respondents brought up the topics. Topics such as learning, practice, and knowledge from senior colleagues are examples for competency, in which learning was commented $69.70 \%$ of total respondent's comments dan $30.30 \%$ for practices..

f. Regulations and practices gap

Loan managers and loan officers concern the gap between regulation and practices on loan restructuring as shown by $75 \%$ of respondents who figure out the topic as material discussion compared to respondents who disagree bringing up the topic. Defining different quality of loan restructuring in practice compared to regulations and find difficulties to fulfil the requirements to restructure the problem loan are the examples of the topic discussion.

\begin{tabular}{|c|c|c|c|c|c|c|c|c|c|c|c|}
\hline Regulations & \multicolumn{3}{|c|}{ Isomorphism } & \multirow{2}{*}{\multicolumn{2}{|c|}{ Losses on Restructuring }} & \multicolumn{2}{|c|}{ Norm or Beliefs } & \multicolumn{2}{|c|}{ Competency } & \multicolumn{2}{|c|}{ Regulations and Practices Gap } \\
\hline $\begin{array}{ll}\text { /PBI } & \text { SOP }\end{array}$ & & tive & tic & & & informal pr & al practices & Learning & ices & ed & xisted \\
\hline $100.00 \%$ & $17.95 \%$ & $69.23 \%$ & $12.82 \%$ & $57.14 \%$ & $42.86 \%$ & $59.65 \%$ & $40.35 \%$ & $69.70 \%$ & $30.30 \%$ & $75.00 \%$ & 25.00 \\
\hline
\end{tabular}

Figure 3 The Most Concerned Topics by Respondents

From the topics discussed above, regulations dominate the discussion as compared to others. Other issues such as accounting difficulties, bonus, and income are examples for loss on restructuring. Interestingly, informal practices have the most topic to be discussed such as knowledge from senior colleagues, belief to borrower repayment capacity and normative isomorphism which are related to logics developed by loan managers and loan officers for doing restructuring or not restructuring the problem loans. It is interesting to figure out that symbolic carriers and material carriers are also included being the most discussed topics in regulations and practices of loan 
restructuring. This indicates the behaviour of loan managers and loan officers when putting the answers in the questionnaires.

Related to analytical and descriptive or case coding, institutional logics (symbolic carriers, material carriers, and isomorphism) were found in the questionnaires: (1) How long have loan managers or loan officers been working at BPR? (2) What is your current position at BPR? (3) What are the intern and extern regulations applied for BPRs' loan restructuring? (4) Give some explanations about any norms or beliefs other than regulations used as guidelines in considering the loan restructuring in BPR? (5) What are the factors as the motivations (coercive, normative, mimetic isomorphism) of loan managers and loan officers to restructure the troubled loan? (6) Are there any other motivations for loan managers and loan officers to make the restructuring decisions? (7) What do the actors do to enhance their understanding of rules/regulations/standards related to loan restructuring? (8) What are the gaps between regulations and practices occurred on loan restructuring? (9) How do they respond to losses due to loan restructuring as a result of restructuring accounting treatment? Please refer to Figure 4.

1. Responses to Question No.1 - How long have loan managers or loan officers been working at BPR?

Most of the respondents have adequate experiences as loan managers or loan officers representing BPRs in West Java Province to answer the questionnaires provided in this research. The questionnaires data shows $38.71 \%$ of respondents have more than two years to five years experiences, and $51.61 \%$ of respondents have been working over six years. Only $9.68 \%$ of respondents obtained less than one-year of experience as loan managers or loan officers at BPR.

2. Responses to Question No.2 - What is your current position at BPR?

This study consists of two actors in BPRs who has the responsibility to continue the loan restructuring process. Two of them are loan managers and loan officers. However, some BPR directors were involved in addressing the questions given for only who had experiences as loan officers or loan managers at BPRs. The data shows that respondents of the questionnaires are $68.33 \%$ and $31,67 \%$ respectively, for loan managers and loan officers.

3. Responses to Question No.3 - What are the intern and extern regulations applied for BPRs' loan restructuring? Please describe.

A majority of loan managers and loan officers $(84.51 \%)$ revealed that SOP and OJK or BI regulations were referenced in conducting loan restructuring while (15.49\%) considered other intern BPR's rules.

4. Responses to Question No.4 - Give some explanations about any norms or beliefs other than regulations used as guidelines in considering the loan restructuring in BPR?

There are 4 (four) themes that were discussed out of the question related to norms and beliefs of loan managers and loan officers, in the following aspects: (1) financial (40.35\% of all comments), (2) character (42.11\% of all comments), (3) policy (10.53\% of all comments), and (4) collateral (7.02\% of all comments).

5. Responses to Question No.5 - What are the factors as the motivations (coercive, normative, mimetic isomorphism) of loan managers and loan officers to restructure the troubled loan? You may answer more than one type of isomorphism. Give some backgrounds to your answers.

Normative isomorphism chosen by most of the respondents reflected $69.23 \%$ of total comments, while only $17.95 \%$ relied on isomorphism coercive and mimetic isomorphism as much as only $12.82 \%$ of total comments.

6. Responses to Question No.6 - Are there any other motivations for loan managers and loan officers to do the restructuring decisions?

There are four "words" frequently commented by respondents related to other motivation may influence the loan restructuring decision, such as the financial condition of the borrower (52.63\%), target defined by management $(39.47 \%)$, internal pressures $(2.63 \%)$, and external economic factor (5.26\%). 
7. Responses to Question No.7 - What do the actors do to enhance their understanding of rules/ regulations/standards related to loan restructuring?

$69.70 \%$ of loan managers and loan officers comments dominate the open-ended question related to the way taken in understanding the regulations or standard of loan restructuring, while $30.30 \%$ tend to do practices to conduct loan restructuring. The comments are frequently used related to learning such as socialization, asking senior, and self-learning, while practices refer to visit the location, learning by doing, or direct verification to the borrower.

8. Responses to Question No.8 - What are the gaps between regulations and practices occurred on loan restructuring?

$75 \%$ of loan managers and loan officers comments that there is a lack of regulations compared to practices on loan restructuring. The words refer to loan quality, external situation, information bias from borrowers, the financial report is not real, and avoid the provision. However, $25 \%$ of respondents comments showed no issues in the gap of regulations to practices.

9. Responses to Question No.9 - How do they respond to losses due to loan restructuring as a result of restructuring accounting treatment?

More than half of respondents (57.14\%) commented that losses recognized at the beginning of loan restructuring are taken as consideration to reject the loan restructuring, while $42.86 \%$ of them tended not to consider the losses and kept continuing the loan restructuring.

\section{Comparative of Respondents}
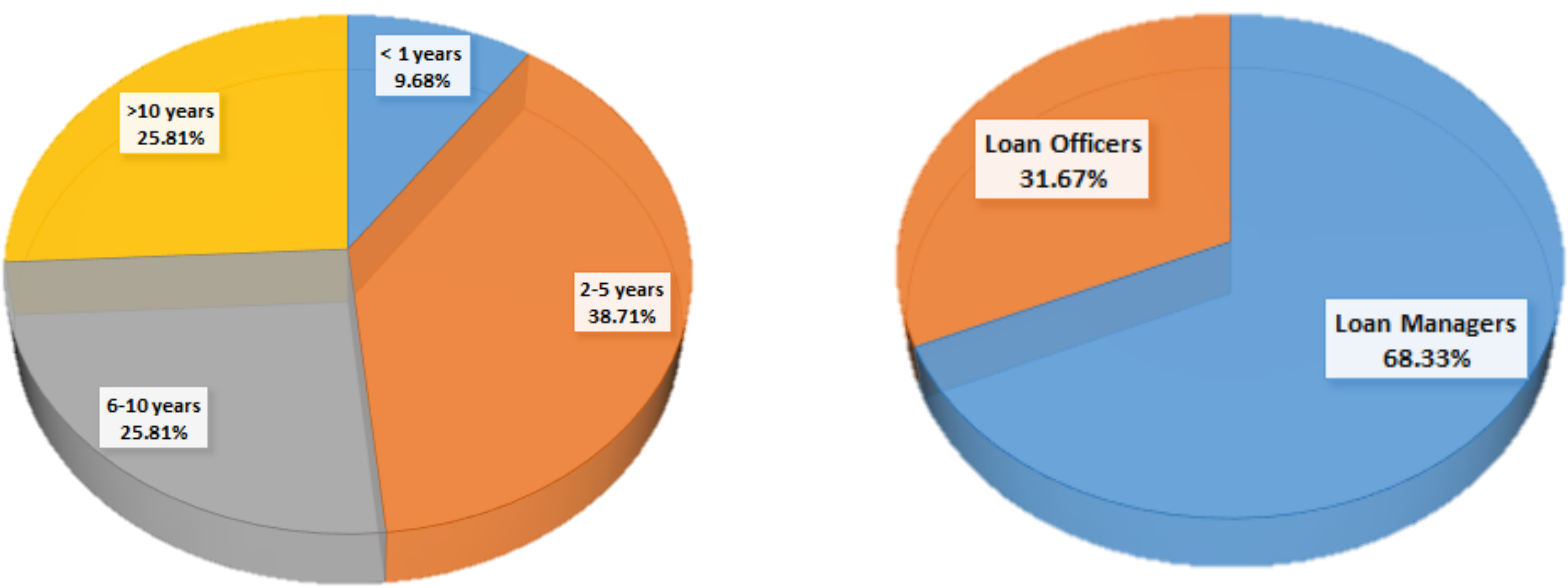

Figure 4 Respondents' Response to Questionnaires

\section{Regulations Referred to Loan Restructuring}

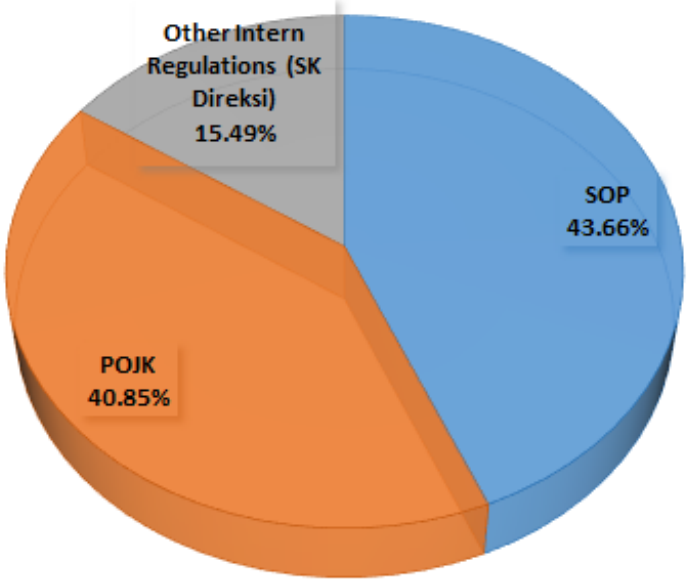

Norms or Beliefs Used as Guidelines in Loan Restructuring

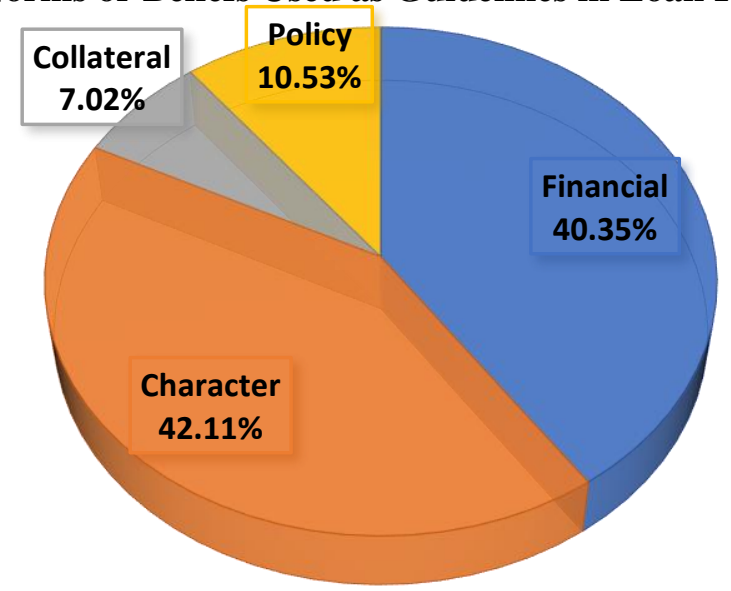


The Motivation Factors (Coercive, Normative, Mimetic Isomorphisms)

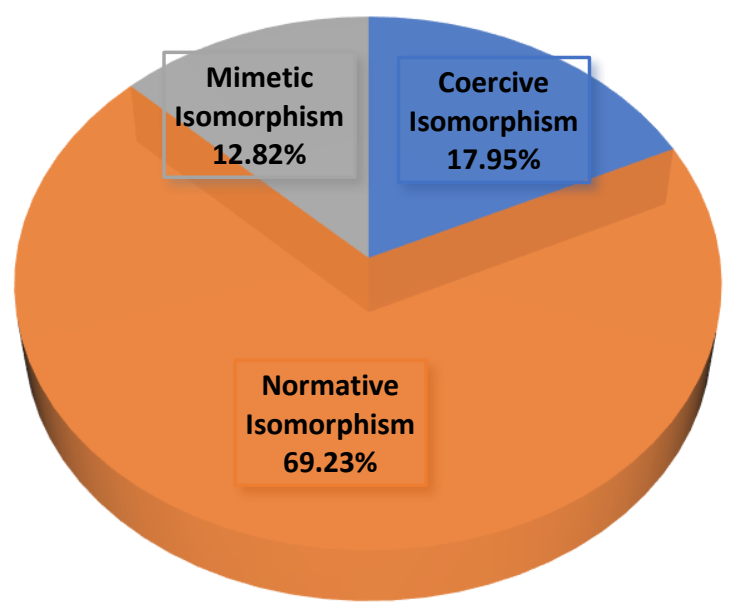

Understanding The Rules/Regulations/ Standards Related to Loan Restructuring

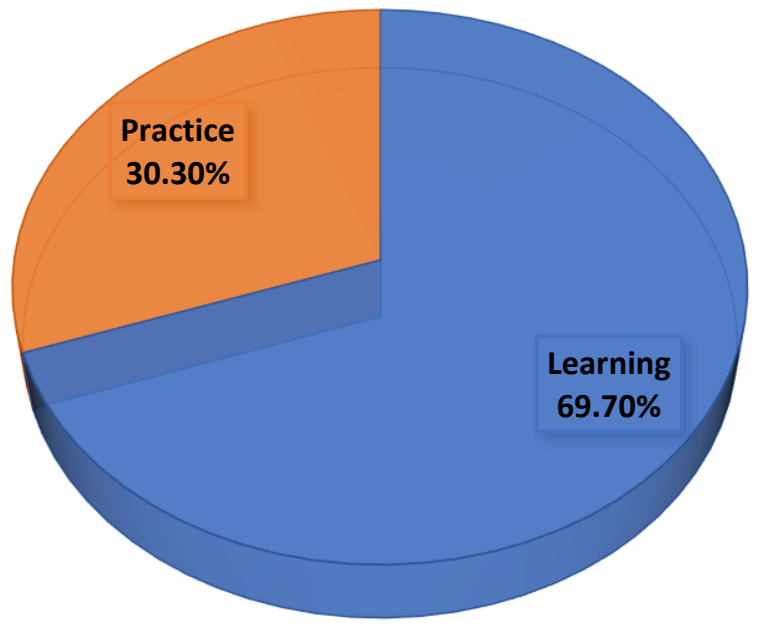

Other Motivations to Perform Restructuring

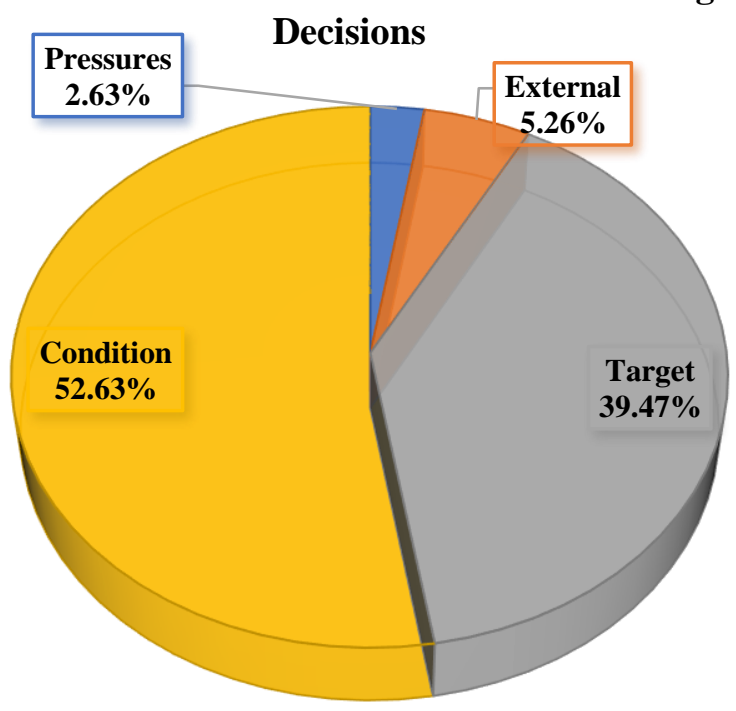

Regulations Versus Practices Gap

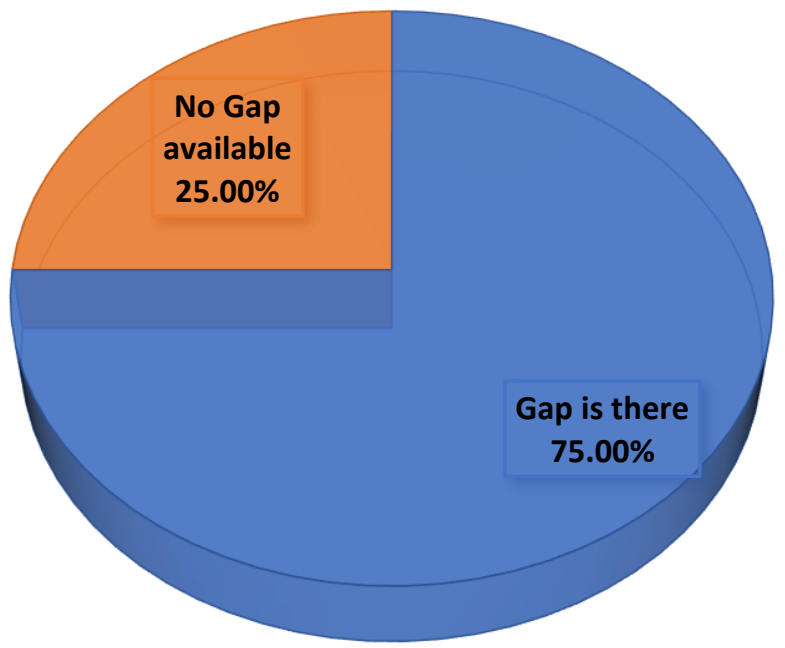

Response to Losses Due to Loan Restructuring As Result of Restructuring Accounting Treatment

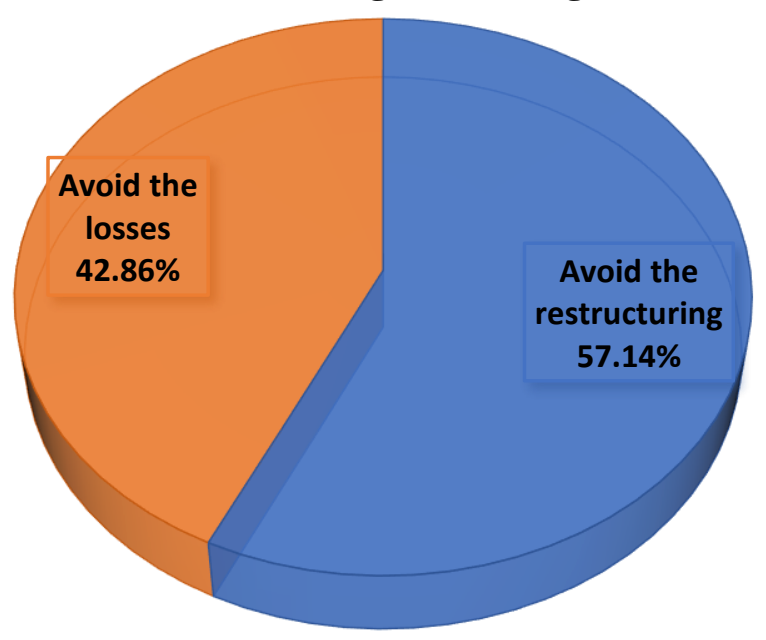




\subsection{Discussion}

This study reveals symbolic carriers in the context of BPR industry like the following (Figure 5):

1. BPR industry has a symbolic carrier that includes regulations issued by authorities such as OJK and Bank Indonesia, also comprises internal BPR regulations referring to general principles set by regulators.

2. POJK and PBI are general rules and principle-based regulations as references for the industry to formulate internal rules more detailed in implementation regulations or operational standards including criteria for conducting loan restructuring, while Financial Accounting Standards and Accountancy Guidelines for BPR issued by the IAI regulates the recognition and accounting treatment which includes accounting for credit restructuring in BPR.

3. It is interesting that there are several informal practices adopted as symbolic factors which influences the behavior both of loan managers and loan officers in accepting the loan restructuring applications proposed by borrowers. It explains that loan managers and loan officers own their informal practices as norms or beliefs to decide application prior submitted.

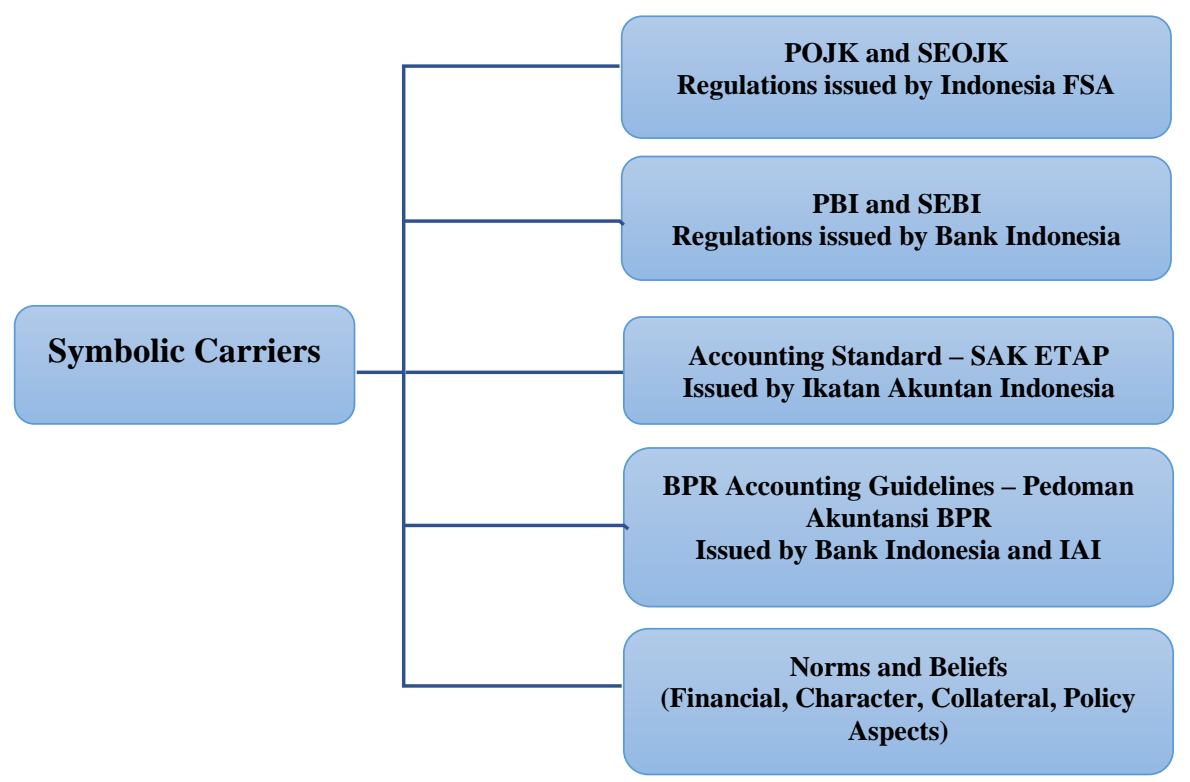

Figure 5 Symbolic Carriers of Loan Restructuring

Despite symbolic carriers, organizations generally considering material carriers in institutions (Scott, 2008). The material of loan restructuring carriers in the BPR Industry in this study uses three carriers, which are: (1) actors responsible for performing non-performing loan restructuring practices in BPRs, (2) artefacts and (3) routines.

The responsible actors are loan managers and loan officers, but on a small scale BPR with a limited number of employees, the responsibility is also carried out by the director of BPR. Artefacts in this study are interpreted as something made by internal companies in order to assist the implementation of tasks related to the logic of loan restructuring behavior such as learning from senior, practices (learning by doing) and target defined by management which are usually used as tools for loan manager and loan officer in conducting loan restructuring processes.

Routines are determined based on the experience of the actors who have the authority to decide the application of loan restructuring. Furthermore, routines in this study refer to the definition put forward by Scott $(1995,2001)$, namely habits such as informal practices, SOP (formal practices) and accounting treatment (losses on restructuring) that become behavioral or work patterns that reflect knowledge 
possessed and conveyed by actors. All three material carriers are found in this study showed in Figure 6.

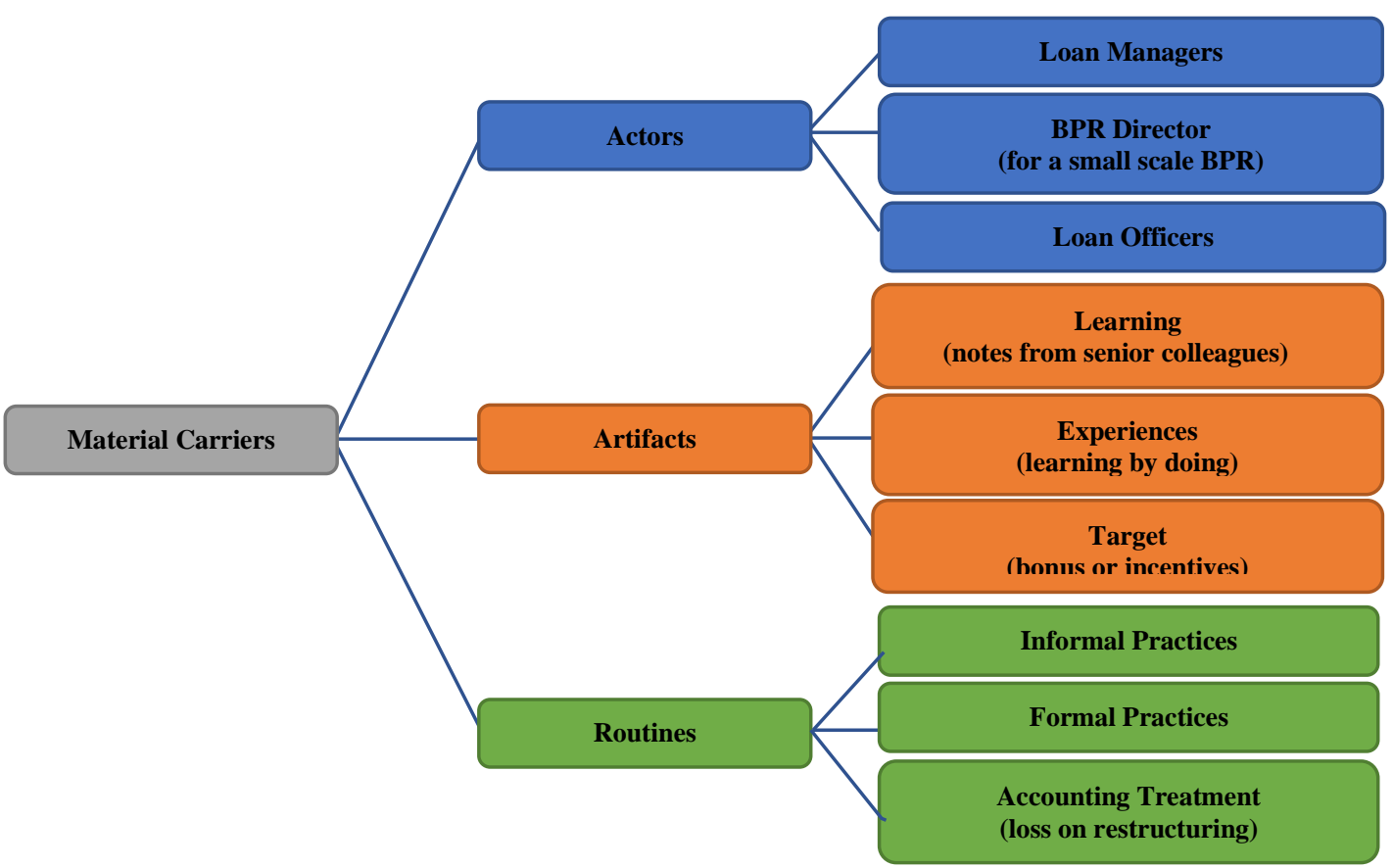

Figure 6 Material Carriers of Loan Restructuring

Based on the findings above, the following research questions can be answered:

(1) The behavior of actors who tend to be reluctant in loan restructuring is influenced by:

(a) The existence of norms or beliefs that loan restructuring will have an impact on losses so that it will interfere with the performance (target) of each actor.

(b) There are regulations gap compared to practices when the actor conducted a loan restructuring, in which the regulations issued such as Bank Indonesia Regulation Number 13/26 / PBI / 2011 concerning Amendments to PBI Number 8/19 / PBI / 2006 concerning Earning Asset Quality and Establishment of Allowance for Earning Assets of Rural Banks, and PBI Number 8/19 / PBI / 2006 concerning Earning Assets Quality and Allowance for Earning Assets of Rural Banks, do not provide relaxation for BPR in improving loan quality.

(c) Some actors who do not have adequate competence to conduct loan restructure, think that learning through practice is much more comfortable, while BPR they work have not carried out loan restructuring.

(d) The financial conditions of the borrowers do not support the BPR to conduct loan restructuring.

(2) Regulations issued by authorities such as OJK, Bank Indonesia, and Accounting Standards that must be compiled by the actors. Not only external regulations as mentioned but also internal rules related to loan restructuring is considered by the actors to decide loan restructuring. These symbolic carriers resulted in the informal practices to fill the gap between regulations and practices of loan restructuring.

(3) The similarity behavior amongst the actors at BPR industry are normative isomorphism due to the banking industry (such as BPR) a highly regulated industry. Thus it is common that loan managers and loan officers tend to figure out norms or rules as factors that drive reluctance to loan restructuring.

Two main conditions regarding the explanation above are representing the behavior of loan managers and loan officers. Symbolic carriers and material carriers influence them for putting less attention on loan restructuring as mitigation for bad debt, even though borrower proposed the application of loan restructuring. Secondly, 
there is similarity for actors' reasons to ignore troubled debt restructuring due to some difficulties to recognize loss occurred on the beginning period of restructuring.

\section{CONCLUSIONS AND SUGGESTIONS}

Based on the analysis result of 60 out of 290 BPRs' managers or officers who are responsible for loan restructuring in West Java, some conclusions are:

1. OJK or Bank Indonesia Regulation is the most considered factor influencing loan managers and loan officers in accepting or rejecting the loan restructuring proposal. It confirms the banking industry as highly regulated institutions.

2. There is no evidence for loan managers and loan officers to ignore the regulation as an anticipating strategy for the profit decrease using loan restructuring. Moreover, it proves loan managers and loan officers taking into account the loss resulted in loan restructuring. It also answers why they reluctant to take loan restructuring for NPL recovery. Subsequently, bonus and incentives influenced the actors for rejecting the loan restructuring as affected the achievement of profit target for BPR.

3. It is also interesting that this study also reveals some informal practices factors (such as norms and beliefs) that may affect loan restructuring process before the application of loan restructuring submitted to BPR.

4. Most of the loan managers and loan officers have adequate experiences and competencies to organize loan restructuring. This conclusion is supported by the evidence that the actors find some ways in learning from senior colleagues and learning by practice directly.

5. The similarity of actors' behavior is the difficulties to recognize loss occurred in the beginning period of restructuring.

Based on the conclusion, this study suggests:

1. Though the experiences and competencies of loan managers and loan officers are mostly adequate, some of them do not yet understand the accounting concept of losses occurred on loan restructuring because they do not want to throw out bonuses or incentives regarding the target defined by management. It is expected that managers and officers knowledge on accounting standards need to be improved.

2. Regulator (OJK) may need to stimulate BPRs in adopting loan restructuring as mitigation of credit risk for non performing loans, such as providing the relaxation on loan restructuring regulation.

3. Escalate research samples, not only in West Java Province but also in wider regional to study the possible factors that could influence the behaviour of loan managers and loan officers related to loan restructuring.

\section{References}

Bank Indonesia. (2006). Peraturan Bank Indonesia Tentang Kualitas Aktiva Produktif Dan Pembentukan Penyisihan Penghapusan Aktiva Produktif Bank Perkreditan Rakyat. Nomor: 8/26/PBI/2006.

Bank Indonesia. 2006. Peraturan Bank Indonesia No. 13/26/PBI/2006 tentang Perubahan Atas PBI Nomor 8/19/PBI/2006 tentang Kualitas Aktiva Produktif Dan Pembentukan Penyisihan Penghapusan Aktiva Produktif Bank Perkreditan Rakyat.

Bank Indonesia. 2006. Peraturan Bank Indonesia No. 8/19/PBI/2006 tentang Kualitas Aktiva Produktif Dan Pembentukan Penyisihan Penghapusan Aktiva Produktif Bank Perkreditan Rakyat.

Bank Indonesia. 2009. Surat Edaran Bank Indonesia Nomor 14/26/DKBU tentang Pedoman Standar Kebijakan Perkreditan BPR. 
Bank Indonesia. (2010). Pedoman Akuntansi Bank Perkreditan Rakyat.

Birmingham, P., \& Wilkinson, D. (2003). Using research instruments: A guide for researchers. Routledge.

Boeker, W. (1989). Strategic change: The effects of founding and history. Academy of Management journal, 32(3), 489-515.Dardac, N., Barbu, T. C., \& Boitan, I. A. (2011). Impact of credit restructuring on the quality of bank asset portfolio. A cluster analysis approach. Acta Universitatis Danubius. Economica, 7(3).

Davis, G. F. (1991). Agents without principles?: The spread of the poison pill through the intercorporate network. Administrative Science Quarterly, 36, 583-613.

DiMaggio, P. J., \& Powell, W. W. 1983. The iron cage revisited: Institutional isomorphism and collective rationality in organizational fields. American Sociological Review, 48(2): 147-160.

DiMaggio, P. (1988). Interest and agency in institutional theory. Institutional patterns and organizations culture and environment, 3-21.

Friedland, R., \& Alford, R. R. (1991). Bringing society back in: Symbols, practices and institutional contradictions.

Galaskiewicz, J., \& Wasserman, S. (1989). Mimetic processes within an interorganizational field: An empirical test. Administrative Science Quarterly, $34,454-477$.

Gilbert, C. G. (2005). Unbundling the structure of inertia: Resource versus routine rigidity. Academy of management journal, 48(5), 741-763.

Gilson, S. C., John, K., \& Lang, L. H. (1990). Troubled debt restructurings: An empirical study of private reorganization of firms in default. Journal of financial economics, 27(2), 315-353.

Glynn, M. A., \& Abzug, R. (2002). Institutionalizing identity: Symbolic isomorphism and organizational names. Academy of Management journal, 45(1), 267-280.

Ikatan Akuntansi Indonesia. 2009. Standar Akuntansi Keuangan Entitas Tanpa Akuntabilitas Publik. Jakarta: Dewan Standar Akuntansi Keuangan.

Jepperson, R. (1991). Institutions, institutional effects, and institutionalism. The new institutionalism in organizational analysis, 143-163.

Johansen, C. B., \& Waldorff, S. B. (2017). What are Institutional Logics-and Where is the Perspective Taking Us?. In New Themes in Institutional Analysis (pp. 5176). Edward Elgar Publishing, Incorporated.

Laryea, T., \& Laeven, M. L. (2009). Principles of household debt restructuring (No. 2009-2015). International Monetary Fund.

Laryea, T. (2010). Approaches to corporate debt restructuring in the wake of financial crises. International Monetary Fund.

Lawrence, T., Suddaby, R., \& Leca, B. (2011). Institutional work: Refocusing institutional studies of organization. Journal of management inquiry, 20(1), 5258 .

Lawrence, T. B., \& Suddaby, R. (2006). Institutions and Institutional Work. SR Clegg, C. Hardy, TB Lawrence \& WR Nord (eds.) Handbook of Organization Studies. 215-254. Sage. March, JG (1991) Exploration and Exploitation in Organizational Learning. Organization Science, 2(1), 71-87.

Lawrence, T. B., Leca, B., \& Zilber, T. B. (2013). Institutional work: Current research, new directions and overlooked issues. Organization Studies, 34(8), 1023-1033. 
Lepoutre, J. M., \& Valente, M. (2012). Fools breaking out: The role of symbolic and material immunity in explaining institutional nonconformity. Academy of Management Journal, 55(2), 285-313.

Micucci, G., \& Rossi, P. (2010). Debt restructuring and the role of lending technologies.

Micucci, G., \& Rossi, P. (2017). Debt restructuring and the role of banks' organizational structure and lending technologies. Journal of Financial Services Research, 51(3), 339-361.

Mizruchi, M. S., \& Stearns, L. B. (1988). A longitudinal study of the formation of interlocking directorates. Administrative Science Quarterly, 33, 194-210.

Parker, L. "Social and Environmental Accountability Research: A View from the Commentary Box." Accounting, Auditing \&Accountability Journal18, No. 6 (2005): 842-60.

Otoritas Jasa Keuangan. Statistik Perbankan Indonesia. 2017. https://www.ojk.go.id/id/kanal/perbankan/data-dan-statistik/statistik perbankanindonesia/ Documents/Pages/Statistik-PerbankanIndonesiaDesember 2017/SPI\%20Desember\%20 2017.pdf

Otoritas Jasa Keuangan. Laporan Triwulanan. Triwulan IV-2017. https://www.ojk.go.id/id/data-dan-statistik/laporan-triwulanan/Documents/ Laporan\%20Triwulan\%20OJK\%20IV-2017.pdf

Republik Indonesia. Undang-Undang No. 10 Tahun 1998 tentang Perbankan. Sekretariat Negara, Jakarta.

Schramm, W. (1971). Notes on Case Studies of Instructional Media Projects.

Scott, W. R. (1995). Institutions and organizations. Sage: Thousand Oaks, CA.

Scott, W. R. (2001). Institutions and organizations. 2nd edn. Sage: Thousand Oaks, CA.

Scott, W. R. (2008). Institutions and organizations: Ideas and interests. Sage.

Scott, W. R. 2008a. Approaching adulthood: The maturing of institutional theory. Theory and Society, 37(5): 427-442.

Shauki, E.R.,"Qualitative and Mixed-Method Research Analysis Using Nvivo11", Handout, CASE WRITING AND METHODOLOGY, ECAM 809303. University of Indonesia, April 2018, Print.

Suddaby, R. (2013). Institutional theory. The Sage Encylopaedia of Management Theory, 379-38.

Thornton, P. H., \& Ocasio, W. (1999). Institutional logics and the historical contingency of power in organizations: Executive succession in the higher education publishing industry, 1958-1990. American journal of Sociology, 105(3), 801-843.

Thornton, P. H., \& Ocasio, W. (2008). Institutional logics. The Sage handbook of organizational institutionalism, 840, 99-128.

Thornton, P. H., Ocasio, W., \& Lounsbury, M. (2012). The institutional logics perspective: A new approach to culture, structure, and process. Oxford University Press on Demand.

Tuttle, B., \& Dillard, J. (2007). Beyond competition: Institutional isomorphism in US accounting research. Accounting Horizons, 21(4), 387-409. 
AFEBI Accounting Review (AAR)

Vol.04 No.01, June 2019

Zietsma, C., \& Lawrence, T. B. (2010). Institutional work in the transformation of an organizational field: The interplay of boundary work and practice work. Administrative science quarterly, 55(2), 189-221.

Zilber, T. B. (2009). Institutional maintenance as narrative acts. Institutional work: Actors and agency in institutional studies of organizations, 205-235.

Zilber, T. B. (2013). Institutional logics and institutional work: Should they be agreed? In Institutional logics in action, Part A (pp. 77-96). Emerald Group Publishing Limited.

Zuckerman, E. W. (1999). The categorical imperative: Securities analysts and the illegitimacy discount. American journal of sociology, 104(5), 1398-1438. 